\title{
Malpractice Litigation in Ocular Oncology
}

\author{
Stephanie B. Engelhard ${ }^{a}$ Mary E. Aronow ${ }^{c}$ Christopher T. Shah ${ }^{d}$ Austin J. Sim $^{b}$ \\ Ashvini K. Reddyc \\ ${ }^{a}$ Department of Ophthalmology, and b School of Law and School of Medicine, University of Virginia, Charlottesville, VA, \\ 'Wilmer Eye Institute, Johns Hopkins University, Baltimore, MD, and d Carolina Eye Associates, Southern Pines, NC, USA
}

\section{Keywords}

Melanoma - Sebaceous cell carcinoma - Retinoblastoma •

Litigation · Malpractice · Lawsuit

\begin{abstract}
Aims: The aim of this study was to report and analyze the causes and outcomes of ocular oncology malpractice litigation. Methods: The WestLaw ${ }^{\circledR}$ database was reviewed for all litigation related to ophthalmology in the United States from 1930 to 2014 . All ocular oncology cases were included in this analysis and compared to other ophthalmic subspecialties. Results: Sixteen ocular oncology malpractice cases were included in this study. Overall, $56.3 \%$ of the cases were resolved in favor of the defendant. A total of $62.5 \%$ of cases were resolved via jury verdict, with $30.0 \%$ resulting in plaintiff verdicts with mean adjusted awards of USD 511,244.48, comparable to ophthalmology as a whole. Three cases (18.8\%) resulted in settlements with mean adjusted indemnities of USD $828,928.14$. A total of $87.5 \%$ of cases alleged insufficient intervention resulting in loss of vision and/or death. The most common clinical entities were uveal melanoma $(31.3 \%)$, retinoblastoma (12.5\%), and sebaceous cell carcinoma (12.5\%). Conclusions: Ocular oncology malpractice litigation was relatively rare and outcomes generally favored defendants; however, unlike other subspecialties in
\end{abstract}

ophthalmology, blindness or premature death were common to all cases, highlighting both the importance of prompt diagnosis and treatment and the difficulty inherent in diagnosing ocular malignancies.

(c) 2017 S. Karger AG, Basel

\section{Introduction}

Medical malpractice litigation exists to ensure that patients harmed by medical negligence are fairly compensated; however, studies have shown that $97-98 \%$ of patients who experience negligent injury do not sue [1-3]. Still, medical malpractice claims are common. According to a 2010 survey conducted by the American Medical Association, $5 \%$ of all physicians in the United States faced a malpractice claim in the preceding year $[4,5]$. Many authors have argued that the malpractice system in its current state is ill equipped to fulfill its purpose and leads to increased healthcare spending secondary to the practice of defensive medicine, higher insurance premiums, and the inability of the system to ensure that justice is

A portion of this work was presented at the ARVO meeting in Baltimore, MD, USA, in May 2017.

\section{KARGER}

(c) 2017 S. Karger AG, Basel

E-Mail karger@karger.com

www.karger.com/oop
Ashvini K. Reddy, MD

Wilmer Eye Institute, Johns Hopkins University

600 N Wolfe Street, Woods \#472

Baltimore, MD 21231 (USA)

E-Mail areddy16@jhmi.edu 
consistently and uniformly achieved [2-10]. The study of medical malpractice serves several ends. It allows physicians to recognize common causes of litigation both in terms of clinical entities and type of complaint. In so doing, not only does malpractice teach methods of mitigating risk, but also, and most importantly, it serves as a reminder to keep a broad differential, perform thorough but appropriate workups for every patient, and foster positive physician-patient relationships.

Several publications focus on litigation in ophthalmology [11-18]; however, there is no study focused specifically on ocular oncology in the literature to our knowledge. Ocular oncology represents a wide range of diseases involving not only the eye itself, but also the orbit and adnexal structures. Furthermore, ocular malignancies are serious diagnoses requiring prompt diagnosis and management to avoid or mitigate disability or death from the malignancy. Because most patients do not present to an ocular oncologist, it is especially important that all ophthalmologists are aware of and prepared to act on suspicious lesions. The purpose of this study is to draw attention to ocular oncology, to recognize clinical entities that commonly result in litigation, and to serve as a guide for physicians to provide a high level of care while minimizing litigation risk.

\section{Methods}

Because all data in this study are publicly available and no human subjects were involved, institutional review board review and informed consent were not necessary. Data are reported by location and year of filing in order to maintain the confidentiality of the physicians and patients named.

WestLaw $^{\circledR}$ (Thomson Reuters, New York, NY, USA) is a legal database that contains verdicts, rulings, and formal settlements in all 50 states. As described in previous publications $[11,12]$, the database was queried to search all US civil trials involving ophthalmologists using the search terms "ophthalmology" or "ophthalmologist" and "malpractice" anywhere in the retrieved documents. Exclusion criteria included (1) ophthalmologist named as expert witness but not defendant and (2) filings before January 1 , 1930, or after December 31, 2014. All search results that referenced malpractice litigation but that were not themselves malpractice lawsuits were excluded (A.J.S.). Duplicate lawsuits or WestLaw ${ }^{\circledR}$ citations were also combined and represented as a single case (A.J.S. and A.K.R.). Record review included date of occurrence, year of suit, defendant, geography, patient age, patient sex, diagnosis, outcome, presence of disability, nature of injury, plaintiff legal allegation, indemnity, verdict, and plaintiff award. Legal blindness was defined as visual acuity of 20/200 or less in the eye or eyes related to the case, and/or a visual field of 20 degrees or less, as this is the standard used to determine eligibility for disability [19].
Not all information was available for every case. Cases were also categorized by intervention (surgical/procedural, medical, or noninterventional) and by subspecialty focus by a faculty ophthalmologist (A.K.R.). The subspecialty focus of the case was defined based on the nature of the allegation rather than the subspecialty training of the physician defendant. When subspecialty focus was unclear or divided (i.e., child with keratoconus and strabismus), subspecialty focus was cataloged as "unknown" or assigned by best judgment of the senior author (A.K.R.). Settlements and awards were adjusted for inflation to 2015 USD (http://www.bls.gov/data/inflation_calculator.htm) to permit meaningful comparison.

In this analysis, all malpractice litigation involving ocular oncology was identified from a database of 1,063 ophthalmology litigation cases. Descriptive statistics were used to report our findings.

\section{Results}

Query of the WestLaw ${ }^{\circledR}$ database for the terms "ophthalmology" or "ophthalmologist" and "malpractice" yielded 1,261 appellate cases and 1,294 jury verdicts/settlements; 1,063 cases met inclusion criteria. Sixteen ocular oncology malpractice cases were identified from the database, representing $1.5 \%$ of total cases. The 16 ocular oncology cases identified occurred between 1971 and 2013. Eleven cases (68.8\%) involved female plaintiffs. Three cases (18.8\%) involved pediatric plaintiffs. Overall, 9 cases $(56.3 \%)$ were resolved in favor of the defendant. Ten cases $(62.5 \%)$ were resolved by means of jury trial. Of these 10 cases, 7 (70\%) were associated with defense verdicts. Three cases $(30.0 \%)$ were resolved in favor of the plaintiffs and resulted in a mean adjusted jury award of USD 511,244.48 (range 192,190.32-839,140.85). Three cases $(18.8 \%)$ resulted in settlements with mean adjusted indemnities of USD 828,928.14 (range 408,437.52$1,261,538.02)$. Of the remaining 3 cases, 2 (12.5\%) were resolved via appellate ruling and $1(6.3 \%)$ was resolved via post-trial relief. All cases by year, state, method of resolution, monetary award with adjustment to 2015 standard, and narrative description are found in Table 1.

Failure to diagnose uveal melanoma was the most common diagnosis in this series and accounted for 5 cases (31.3\%). Only 1 case resulted in a payment to the plaintiff in the amount of USD 408,357.52. None of the defendants in these 5 cases were ocular oncologists; however, at least 4 were fellowship trained in other subspecialties. All 5 cases involved allegations of failure to diagnose in a timely fashion. Two cases involved alleged failure to perform adequate exams, resulting in delayed diagnosis and in the development of metastatic melanoma. One of these cases resulted in a payment to the plaintiff. In the case that was resolved in favor of the defendant, the plaintiff al- 
Table 1. Ocular oncology cases by year, state, method of resolution, and monetary award

\begin{tabular}{|c|c|c|c|c|c|c|c|c|c|}
\hline Case & Year & State & Court & $\begin{array}{l}\text { Means of } \\
\text { resolution }\end{array}$ & Verdict & $\begin{array}{l}\text { Award or } \\
\text { indemnity, } \\
\text { USD }\end{array}$ & $\begin{array}{l}\text { Award } \\
\text { adjustment to } \\
2015 \text { USD }\end{array}$ & $\begin{array}{l}\text { Intervention } \\
\text { or legal } \\
\text { allegation }\end{array}$ & Diagnosis and summary \\
\hline 1 & 1971 & MT & $\begin{array}{l}\text { State } \\
\text { supreme }\end{array}$ & $\begin{array}{l}\text { Appellate } \\
\text { ruling }\end{array}$ & Defendant & & & $\begin{array}{l}\text { Non- } \\
\text { interventional }\end{array}$ & $\begin{array}{l}\text { Iris/ciliary body melanoma. Plaintiff alleged that } \\
\text { enucleation resulted from failure to promptly diagnose iris/ } \\
\text { ciliary body melanoma in spite of iris color change }\end{array}$ \\
\hline 2 & 1984 & NY & $\begin{array}{l}\text { State } \\
\text { district }\end{array}$ & Settlement & Plaintiff & $550,000.00$ & $1,261,538.02$ & $\begin{array}{l}\text { Non- } \\
\text { interventional }\end{array}$ & $\begin{array}{l}\text { Sebaceous cell carcinoma. Plaintiff alleged that } \\
\text { enucleation and metastatic spread of sebaceous carcinoma } \\
\text { to the head and neck could have been avoided if patient } \\
\text { had been urged to undergo biopsy for recurrent chalazion }\end{array}$ \\
\hline 3 & 1987 & FL & $\begin{array}{l}\text { State } \\
\text { district }\end{array}$ & Jury verdict & Plaintiff & $400,000.00$ & $839,140.85$ & $\begin{array}{l}\text { Non- } \\
\text { interventional }\end{array}$ & $\begin{array}{l}\text { Orbital tumor. Plaintiff alleged failure to diagnose orbital } \\
\text { tumor during lifetime follow-up for patient with "eye } \\
\text { cancer" as a child }\end{array}$ \\
\hline 4 & 1987 & PA & $\begin{array}{l}\text { State } \\
\text { district }\end{array}$ & $\begin{array}{l}\text { Post-trial } \\
\text { relief }\end{array}$ & Defendant & & & $\begin{array}{l}\text { Non- } \\
\text { interventional }\end{array}$ & $\begin{array}{l}\text { Retinoblastoma. Plaintiffs alleged failure to diagnose } \\
\text { retinoblastoma resulting in enucleation }\end{array}$ \\
\hline 5 & 1989 & FL & $\begin{array}{l}\text { State } \\
\text { district }\end{array}$ & Jury verdict & Plaintiff & $100,000.00$ & $192,190.32$ & $\begin{array}{l}\text { Non- } \\
\text { interventional }\end{array}$ & $\begin{array}{l}\text { Intracranial tumor. Patient alleged blindness following } \\
\text { misdiagnosis of intracranial tumor as glaucoma for } 2 \text { years } \\
\text { resulting in loss of vision in one eye and possible } \\
\text { recurrence after removal }\end{array}$ \\
\hline 6 & 1989 & NY & $\begin{array}{l}\text { State } \\
\text { district }\end{array}$ & Settlement & Plaintiff & $425,000.00$ & $816,808.87$ & $\begin{array}{l}\text { Non- } \\
\text { interventional }\end{array}$ & $\begin{array}{l}\text { Sebaceous cell carcinoma. Plaintiff alleged that failure to } \\
\text { diagnose sebaceous cell carcinoma for } 6 \text { years resulted in } \\
\text { enucleation }\end{array}$ \\
\hline 7 & 1990 & CA & $\begin{array}{l}\text { State } \\
\text { district }\end{array}$ & Settlement & Plaintiff & $224,000.00$ & $408,437.52$ & $\begin{array}{l}\text { Non- } \\
\text { interventional }\end{array}$ & $\begin{array}{l}\text { Choroidal melanoma. Plaintiff alleged failure to diagnose } \\
\text { choroidal melanoma, promptly resulting in metastatic } \\
\text { spread to plaintiff's liver }\end{array}$ \\
\hline 8 & 1991 & PA & $\begin{array}{l}\text { State } \\
\text { district }\end{array}$ & Jury verdict & Defendant & & & $\begin{array}{l}\text { Non- } \\
\text { interventional }\end{array}$ & $\begin{array}{l}\text { Parotid gland malignancy. Plaintiff alleged that failure to } \\
\text { diagnose malignant parotid gland tumor caused decreased } \\
\text { quality and length of life }\end{array}$ \\
\hline 9 & 1992 & DC & $\begin{array}{l}\text { State } \\
\text { appeals }\end{array}$ & $\begin{array}{l}\text { Appellate } \\
\text { ruling }\end{array}$ & Plaintiff & & & $\begin{array}{l}\text { Non- } \\
\text { interventional }\end{array}$ & $\begin{array}{l}\text { Lacrimal gland adenocarcinoma. Plaintiff alleged loss of } \\
\text { vision due to failure to diagnose lacrimal gland } \\
\text { adenocarcinoma }\end{array}$ \\
\hline 10 & 1992 & MA & $\begin{array}{l}\text { State } \\
\text { district }\end{array}$ & Jury verdict & Defendant & & & $\begin{array}{l}\text { Surgical/ } \\
\text { procedural }\end{array}$ & $\begin{array}{l}\text { Basal cell carcinoma. Plaintiff alleged that failure to } \\
\text { diagnose basal cell carcinoma in the lateral canthus } \\
\text { required surgery that resulted in blindness }\end{array}$ \\
\hline 11 & 1994 & NY & $\begin{array}{l}\text { State } \\
\text { district }\end{array}$ & Jury verdict & Defendant & & & $\begin{array}{l}\text { Surgical/ } \\
\text { procedural }\end{array}$ & $\begin{array}{l}\text { Orbital tumor. Plaintiff alleged that removal of excessive } \\
\text { tissue during orbital tumor removal resulted in loss of } \\
\text { vision }\end{array}$ \\
\hline 12 & 2005 & NY & $\begin{array}{l}\text { State } \\
\text { district }\end{array}$ & Jury verdict & Defendant & & & $\begin{array}{l}\text { Non- } \\
\text { interventional }\end{array}$ & $\begin{array}{l}\text { Choroidal melanoma. Plaintiff alleged that failure to } \\
\text { perform dilated exam resulted in death secondary to failure } \\
\text { to diagnose ocular melanoma }\end{array}$ \\
\hline 13 & 2005 & $\mathrm{AL}$ & $\begin{array}{l}\text { State } \\
\text { district }\end{array}$ & Jury verdict & Defendant & & & $\begin{array}{l}\text { Non- } \\
\text { interventional }\end{array}$ & $\begin{array}{l}\text { Choroidal melanoma. Plaintiff alleged that failure to } \\
\text { diagnose choroidal melanoma resulted in enucleation }\end{array}$ \\
\hline 14 & 2005 & MI & $\begin{array}{l}\text { State } \\
\text { district }\end{array}$ & Jury verdict & Defendant & & & $\begin{array}{l}\text { Surgical/ } \\
\text { procedural }\end{array}$ & $\begin{array}{l}\text { Optic nerve astrocytosis. Plaintiff alleged that } \\
\text { misdiagnosis of optic nerve astrocytosis as an optic nerve } \\
\text { glioma resulted in removal of optic nerve and blindness }\end{array}$ \\
\hline 15 & 2006 & MI & $\begin{array}{l}\text { State } \\
\text { district }\end{array}$ & Jury verdict & Plaintiff & $425,000.00$ & $502,402.28$ & $\begin{array}{l}\text { Non- } \\
\text { interventional }\end{array}$ & $\begin{array}{l}\text { Retinoblastoma. Plaintiff alleged that failure to diagnose } \\
\text { retinoblastoma resulted in enucleation }\end{array}$ \\
\hline 16 & 2013 & MA & $\begin{array}{l}\text { State } \\
\text { district }\end{array}$ & Jury verdict & Defendant & & & $\begin{array}{l}\text { Non- } \\
\text { interventional }\end{array}$ & $\begin{array}{l}\text { Choroidal melanoma. Plaintiff alleged that misdiagnosis } \\
\text { of choroidal melanoma as benign nevus resulted in death } \\
\text { secondary to metastatic spread of melanoma }\end{array}$ \\
\hline
\end{tabular}

leged that the choroidal melanoma had been misdiagnosed as a choroidal nevus and the defendant had failed to perform dilated exams for 2 years. This was denied by the defense.

Two cases (12.5\%) involved delayed diagnosis of sebaceous cell carcinoma. Both cases resulted in settlements with relatively large payments to plaintiffs of USD $1,261,538.02$ and USD 816,808.87.

Two cases (12.5\%) involved delayed diagnosis of retinoblastoma in pediatric patients resulting in enucleation; however, only 1 case resulted in a payment to the plaintiff. In that case, the child's parents had seen a television pro- 
gram about retinoblastoma and were concerned that their son might be suffering from the condition because he had leukocoria in his left eye. The defendant ophthalmologist allegedly informed the parents that their son had tortuous vessels, which signified myopia, and that since retinoblastoma is rare, the parents should not worry. Later that year, the parents noted that the child's eye began to change color. When they returned to the same ophthalmologist, the child was diagnosed with a tumor that occupied $25 \%$ of the child's eye. A second ophthalmologist was consulted and concluded that the child had retinoblastoma with tumor occupying two-thirds of the eye with retinal detachment and that the only option at this advanced stage was enucleation.

The majority of cases (87.5\%) alleged insufficient intervention, including failure to diagnose or misdiagnosis, resulting in disability or death. Of these cases, $46.2 \%$ resulted in payments to plaintiffs.

Three cases $(18.8 \%)$ were related specifically to surgical interventions. None of these cases resulted in payments to plaintiffs. In 1 case, the plaintiff alleged that failure to diagnose basal cell carcinoma in the lateral canthus delayed diagnosis sufficiently to require more extensive resection than would have initially been required and that this extensive resection resulted in preventable loss of vision. Although orbital invasion of basal cell carcinoma is rare, canthal lesions are associated with a higher risk [20].

Ocular oncology represented a small portion of malpractice in ophthalmology; however, rates of defendant verdicts and plaintiff payment amounts were similar to those found in the WestLaw ${ }^{\circledR}$ database for ophthalmology as a whole. The overall rate of plaintiff jury verdicts across all subspecialties in ophthalmology in this series was $29.6 \%$, compared to $30.0 \%$ for ocular oncology. The median plaintiff award for all of ocular oncology was USD 659,606 , compared to USD 568,302 across all subspecialties.

\section{Discussion}

Ocular oncology represented $1.5 \%$ of all ophthalmology cases in the database, which is similar to the $1.2 \%$ (12 cases) reported in a study of ophthalmology malpractice from England's National Health Service Litigation Authority database [21]. Unlike other subspecialties in ophthalmology, in the present analysis, every case in this analysis resulted in either blindness or premature death, highlighting both the importance of prompt diagnosis and treatment of ocular malignancies as well as actively screening for malignancies. In some cases, the delay in diagnosis was several years, highlighting the inherent difficulty in diagnosing cancers in and around the eye. Because ocular malignancies can involve the orbit, the eye itself, and adnexal structures, it is imperative that a full exam is performed to evaluate each of these areas, especially because patients are more likely to present to a community ophthalmologist than an oncology subspecialist.

Uveal melanoma was the most common reason for litigation in this study. Ocular melanoma is rare. It accounts for $3-5 \%$ of all melanomas diagnosed in the United States, with an incidence of 4.3-5.1 per million individuals [22, 23]. A European study found similar incidence results that varied with latitude from a low of $<2$ per million in Spain and southern Italy to a high of $>8$ per million in Norway and Denmark [24]. Uveal melanoma accounts for $85 \%$ of ocular melanoma and is the most common primary intraocular malignancy among adults $[22,23,25$, $26]$. The majority of uveal melanoma originates in the choroid $(90 \%)$, while origin in the ciliary body $(7 \%)$ or iris $(2 \%)$ is less common $[25,26]$. Prognosis depends on a number of factors, including age and sex, tumor diameter, ciliary body involvement, and cytomorphology and genetics [27]. We recommend that careful examination of the eye and adnexal structures be undertaken, especially in patients at higher risk, and careful follow-up of choroidal nevi.

Two cases were related to failure to promptly diagnose sebaceous cell carcinoma, which represents $5 \%$ of eyelid malignancies [28]. This rare eyelid malignancy can demonstrate aggressive local and metastatic behavior and requires a high index of suspicion to diagnose. It has historically been associated with delays in diagnosis, resulting in high morbidity and mortality because it has the potential to masquerade as other conditions [28, 29]. When there is a high index of suspicion, an excisional or incisional biopsy is required as prompt diagnosis can prevent orbital spread and the development of metastatic disease [28].

Retinoblastoma, responsible for 2 cases, has an incidence of 1 in 15,000-20,000 live births [30]. Leukocoria, uveitis, or misalignment in children should prompt ophthalmologists to evaluate for retinoblastoma and document examination findings clearly. Although the 5-year survival rate is $>90 \%$ in developed countries [31], treatment can result in significant disfigurement if not caught early. For these reasons, special care should be taken to fully evaluate children, especially when parents report seeing changes in a child's eye color or reflectance. 
The importance of obtaining proper informed consent is paramount both in terms of ensuring that patients understand the risks, benefits, and alternatives to interventions and procedures and also for the practical purpose of reducing malpractice risk due to improper or inadequate consenting processes [32]. The informed consent process should serve to educate patients not only about the risks of the intervention planned, but also the risks of nonintervention $[33,34]$. Similarly, patients should understand the importance of returning for follow-up visits and should be informed of the possible consequences of not following the recommended follow-up schedule. If patients choose nonintervention or do not adhere to the recommended schedule, this should be thoroughly documented in the medical record. Documenting patients' failure to return to the clinic is important when cases are brought to trial, which has been documented previously [12]. Additionally, patients should be informed of the possibility that surgical plans may shift intraoperatively, a discussion which may have prevented at least 1 case in this series. Ensuring that patients understand these risks increases patient satisfaction and informs patients' expectations [32, 34].

The majority of the literature published on litigation in ophthalmology has come from claims databases that provide comprehensive data from a single insurer $[14,18$, 35-37]. WestLaw ${ }^{\circledR}$, however, is a database of settlements and verdicts from a variety of insurers, which may present a more global picture of litigation in ophthalmology. As we have stated in other reports $[11,12]$, potential limitations include changes in clinical practice over time, including new technology allowing more precise diagnosis and management, and changing patient and physician demographics and cultural values. Additionally, WestLaw $^{\circledR}$ does not include out-of-court settlements and dropped cases, and it has been said that up to $85 \%$ of cases never make it to trial [35]. Finally, the level of detail available for cases varies, and in some cases, additional or clarifying information was not available. In some cases, appellate courts overturned earlier jury decisions and granted new trials; however, in some cases, the later trial information was unavailable. Finally, this analysis is based on 16 cases, and although these cases represent all ocular oncology cases in WestLaw ${ }^{\circledR}$, the sample size is small.

Although ocular oncology is a relatively small field within ophthalmology, it is a subspecialty in which patients often suffer severe disability or death secondary to ocular malignancies themselves or to their metastatic spread. In ocular oncology, as in medicine in general, developing meaningful and positive relationships with patients, educating patients thoroughly about the risks and benefits of procedures, ensuring patient understanding of follow-up schedules and treatment plans, and careful documentation of such are important factors that both promote a high level of patient care as well as act as a deterrent to and protection during litigation. In addition to these practices, it is essential to keep ocular malignancies on the differential for patients with potentially concerning signs and symptoms. Prompt diagnosis and treatment of ocular malignancies is not only vision saving, but potentially also lifesaving.

\section{Statement of Ethics}

Because all data in this study are publicly available and no human subjects were involved, institutional review board review and informed consent were not necessary.

\section{Disclosure Statement}

None of the authors have a proprietary interest. No conflicting relationship exists for any author.

\section{Funding Sources}

There were no funding sources.

\section{References}

1 Localio AR, Lawthers AG, Brennan TA, Laird NM, Hebert LE, Peterson LM, Newhouse JP, Weiler PC, Hiatt HH: Relation between malpractice claims and adverse events due to negligence: results of the Harvard Medical Practice Study III. N Engl J Med 1991;325:245251.
2 Studdert DM, Thomas EJ, Burstin HR, Zbar BI, Orav EJ, Brennan TA: Negligent care and malpractice claiming behavior in Utah and Colorado. Med Care 2000;38:250-260.

3 Studdert DM, Mello MM, Gawande AA, Gandhi TK, Kachalia A, Yoon C, Puopolo AL, Brennan TA: Claims, errors, and compensation payments in medical malpractice litigation. N Engl J Med 2006;354:2024-2033.
4 Jena $A B$, Seabury S, Lakdawalla D, Chandra A: Malpractice risk according to physician specialty. N Engl J Med 2011;365:629-636.

5 Kane CK: Medical liability claim frequency: a 2007-2008 snapshot of physicians. AMA Policy Research Perspectives. August 2010. https:// www.ama-assn.org/sites/default/files/mediabrowser/public/health-policy/prp-201001claim-freq.pdf (accessed April 5, 2016). 
6 Carroll AE, Buddenbaum JL: Malpractice claims involving pediatricians: epidemiology and etiology. Pediatrics 2007;120:10-17.

7 Hillman RJ, Allen KG: Medical Malpractice Insurance: Multiple Factors Have Contributed to Increased Premium Rates. Washington, DC, Government Accounting Office, 2003.

8 Kessler DP, McClellan M: The Effects of Malpractice Pressure and Liability Reforms on Physicians' Perceptions of Medical Care. National Bureau of Economic Research, 1998.

9 Hermer LD, Brody H: Defensive medicine, cost containment, and reform. J Gen Intern Med 2010;25:470-473.

10 Jena AB, Schoemaker L, Bhattacharya J, Seabury SA: Physician spending and subsequent risk of malpractice claims: observational study. BMJ 2015;351:h5516.

11 Reddy AK, Engelhard SB, Shah CT, Sim AJ, Thorne JE: Medical malpractice in uveitis: a review of clinical entities and outcomes. Ocul Immunol Inflamm 2016, Epub ahead of print.

12 Engelhard SB, Collins M, Shah CT, Sim AJ, Reddy AK: Malpractice litigation in pediatric ophthalmology. JAMA Ophthalmol 2016; 134:1230-1235.

13 Kraushar MF: Toward more effective risk prevention. Surv Ophthalmol 2009;54:150-157.

14 Day S, Menke AM, Abbott RL: Retinopathy of prematurity malpractice claims: the Ophthalmic Mutual Insurance Company experience. Arch Ophthalmol 2009;127:794-798.

15 Ali N: A decade of clinical negligence in ophthalmology. BMC Ophthalmol 2007;7:20.

16 Abbott RL, Weber P, Kelley B: Medical professional liability insurance and its relation to medical error and healthcare risk management for the practicing physician. Am J Ophthalmol 2005;140:1106-1111.
17 Mavroforou A, Michalodimitrakis E: Physicians' liability in ophthalmology practice. Acta Ophthalmol Scand 2003;81:321-325.

18 Abbott RL, Ou RJ, Bird M: Medical malpractice predictors and risk factors for ophthalmologists performing LASIK and photorefractive keratectomy surgery. Ophthalmology 2003;110:2137-2146.

19 Social Security Administration: Revised medical criteria for evaluating visual disorders. Final rules. Fed Regist 2006;71:67037-67055.

20 Selva D, Hale L, Bouskill K, Huilgol SC: Recurrent morphoeic basal cell carcinoma at the lateral canthus with orbitocranial invasion. Australas J Dermatol 2003;44:126-128.

21 Mathew RG, Ferguson V, Hingorani M: Clinical negligence in ophthalmology: fifteen years of National Health Service litigation authority data. Ophthalmology 2013;120:859-864.

22 Singh AD, Topham A: Incidence of uveal melanoma in the United States: 1973-1997. Ophthalmology 2003;110:956-961.

23 Singh AD, Turell ME, Topham AK: Uveal melanoma: trends in incidence, treatment, and survival. Ophthalmology 2011;118:18811885.

24 Virgili G, Gatta G, Ciccolallo L, Capocaccia R, Biggeri A, Crocetti E, Lutz JM, Paci E; EUROCARE Working Group: Incidence of uveal melanoma in Europe. Ophthalmology 2007; 114:2309-2315.

25 Shields CL, Kaliki S, Furuta M, Mashayekhi A, Shields JA: Clinical spectrum and prognosis of uveal melanoma based on age at presentation in 8,033 cases. Retina 2012;32:13631372.

26 Tarlan B, Kiratlı H: Uveal melanoma: current trends in diagnosis and management. Turk J Ophthalmol 2016;46:123.
27 Damato B, Eleuteri A, Taktak AF, Coupland SE: Estimating prognosis for survival after treatment of choroidal melanoma. Prog Retin Eye Res 2011;30:285-295.

28 Shields JA, Demirci H, Marr BP, Eagle RC, Shields CL: Sebaceous carcinoma of the ocular region: a review. Surv Ophthalmol 2005; 50:103-122.

29 Shields JA, Demirci H, Marr BP, Eagle RC, Shields CL: Sebaceous carcinoma of the eyelids: personal experience with 60 cases. Ophthalmology 2004;111:2151-2157.

30 Dimaras H, Kimani K, Dimba EA, Gronsdahl P, White A, Chan HS, Gallie BL: Retinoblastoma. Lancet 2012;379:1436-1446.

31 Goddard AG, Kingston JE, Hungerford JL: Delay in diagnosis of retinoblastoma: risk factors and treatment outcome. Br J Ophthalmol 1999;83:1320-1323.

32 Kraushar MF, Steinberg JA: Informed consent: surrender or salvation? Arch Ophthalmol 1986;104:352-355.

33 Kraushar MF: Toward more effective risk prevention. Surv Ophthalmol 2009;54:150-157.

34 Kraushar MF: Medical malpractice experiences of vitreoretinal specialists: risk prevention strategies. Retina 2003;23:523-529.

35 Svider PF, Blake DM, Husain Q, Mauro AC, Turbin RE, Eloy JA, Langer PD: In the eyes of the law: malpractice litigation in oculoplastic surgery. Ophthal Plast Reconstr Surg 2014;30: 119-123.

36 Kim JE, Weber P, Szabo A: Medical malpractice claims related to cataract surgery complicated by retained lens fragments (an American Ophthalmological Society thesis). Trans Am Ophthalmol Soc 2012;110:94.

37 Fountain TR: Ophthalmic malpractice and physician gender: a claims data analysis (an American Ophthalmological Society thesis). Trans Am Ophthalmol Soc 2014;112:38. 